\title{
COLORECTALIS DAGANATOK LAPAROSCOPOS SEBÉSZETE
}

\author{
Lázár György, Paszt Attila, Simonka Zsolt, Rokszin Richárd, \\ Ábrahám Szabolcs
}

Szegedi Tudományegyetem, Általános Orvosi Kar,

Szent-Györgyi Albert Klinikai Központ, Sebészeti Klinika, Szeged

\begin{abstract}
A minimálisan invazív technika - a módszer vitathatatlan elónyei révén - teljesen elfogadottá vált a legtöbb jóindulatú és funkcionális megbetegedés sebészi kezelésében. Napjainkra az is bebizonyosodott, hogy a laparoscopos technika a colorectalis daganatok sebészi kezelésében is biztonsággal alkalmazható. A szerzók saját és a nemzetközi tapasztalatok elemzésével mutatják be a colorectalis daganatok laparoscopos sebészi kezelését. A Szegedi Tudományegyetem ÁOK Sebészeti Klinikáján 2005. január 1. és 2008. december 31. között 74 betegen végeztek laparoscopos/laparoscoposan asszisztált colorectalis bélresectiót. A mütéti indikációt 40 esetben neoplasticus eredetü colorectalis laesio képezte. A betegek átlagos életkora 64 év volt (36-89 év). A betegek közül 4 ASA I, 11 ASA II, 24 ASA III és 1 ASA IV rizikócsoportba tartozott. 26 esetben rectosigmoidealis resectio, 2 esetben rectumexstirpatio, 9 esetben jobb, 1 esetben bal oldali hemicolectomia történt. Sem mütéti, sem posztoperatív szövődmény nem volt. 4 konverzió és egy esetben adhesiós ileus miatt reoperáció történt. A passage megindulása (átlagosan 2,4 nap) és a per os táplálhatóság jelentösen lerövidült. A specimenek hisztológiai feldolgozása minden esetben tumormentes oralis, aboralis és circumferentialis resectiót igazolt. Saját és a nemzetközi eredmények áttekintése alapján megállapitható, hogy colorectalis daganatok miatt végzett laparoscopos mütétek biztonságosak, sebészi és onkológiai szempontból is megfelelőek. Számos előnyt jelentenek a betegek számára elsősorban a korai posztoperatív időszakban (gyorsabb felépïlés, rövidebb kórházi tartózkodás) és a hosszú távú túlélési eredmények is megfelelőek. Magyar Onkológia 54:117-122, 2010
\end{abstract}

Kulcsszavak: laparoscopos/laparoscoposan asszisztált bélresectio, colorectalis tumor, intestinalis resectio, colorectalis laesio, minimálisan invazív sebészet

The minimally invasive technique, by means of the undoubted advantages of the method, has become fully accepted in the surgical treatments of the most benign and functional diseases. Today it has been proven that the laparoscopic technique is safely usable also in the surgical treatment of colorectal tumors. The authors, analyzing their own and the international experiences, present the laparoscopic surgical treatment of colorectal tumors. Seventy-four patients were treated with laparoscopic-assisted colorectal intestinal resection in the Department of Surgery of the University of Szeged between January 1, 2005 and December 31, 2008. The surgical indication was neoplastic colorectal lesion in 40 cases. The average age of them was 64 years (from 36 to 89 years). Four patients belonged to the risk group of ASA I, 11 patients to ASA II, 24 to ASA III, and one to ASA IV. Twenty-six patients underwent rectosigmoideal resection, 2 had rectal exstirpation, 9 had right hemicolectomy and one had left hemicolectomy. There were no surgical or postoperative complications. Four conversions and in one case a reoperation occurred due to adhesion ileus. The startup of the passage (2.4 days, on average) and the possibility of nourishing per os were significantly shortened. The histological processes of specimens justified tumor-free oral, aboral and circumferential resection in all cases. Summarizing our own and international experiences it can be stated that the laparoscopic surgeries performed due to colorectal tumors are safe, and are also appropriate with respect to oncosurgery. There are a number of benefits for the patients mainly in the early postoperative period (faster recovery, shorter hospitalization) and their long-term survival results are good as well. Lázár G, Paszt A, Simonka Z, Rokszin R, Ábrahám S. Laparoscopic surgery in colorectal tumors. Hungarian Oncology 54:117-122, 2010

Keywords: laparoscopy, colorectal tumor, intestinal resection, colorectal lesion, minimally invasive
Közlésre érkezett: 2010. március 16

Elfogadva: 2010. május 6.

Levelezési cím: Dr. Lázár György SZTE ÁOK Sebészeti Klinika 6720 Szeged Pécsi u. 6. Telefon: (06-62) 545-701 Fax: (06-62) 545-701 E-mail: lg@surg.szote.u-szeged.hu 


\section{BEVEZETÉS}

Az elmúlt két évtizedben a minimálisan invazív sebészi technika teljesen megváltoztatta a sebészet szinte minden ágát. A módszer vitathatatlan előnyei révén a legtöbb jóindulatú és funkcionális megbetegedés sebészi kezelésében a laparoscopos/thoracoscopos technika gyorsan elterjedt és napjainkra teljesen elfogadottá vált. A vastagbél-és végbélsebészetben, kezdetben hasonló indikációs területen (diverticulosis és szövődményei, végbélprolapsus, gyulladásos bélbetegségek) történtek az első beavatkozások. Jacobs 1991-ben 20 sikeres colectomiáról számolt be, melyek közül már 12 esetben a mütét javallata rosszindulatú daganat volt. Hamarosan kiderült, hogy a laparoscopos technika a vastagbélsebészetben is biztonsággal alkalmazható és így rövid időn belül egyre többen colorectalis daganatok miatt is végeztek mütétet.

Számos kérdés és aggály fogalmazódott meg sokakban. Végezhető-e egyáltalán minimálisan invazív módszerrel onkológiailag is radikális mütét? Fokozza-e a módszer a tumor esetleges szóródását? Hatással van-e a rövid és a hosszú távú túlélésre? Napjainkban ezek a kérdések már megnyugtatóan megválaszolásra kerültek.

Közleményünkben saját tapasztalatainkat és az ide vonatkozó irodalmi adatokat foglaljuk össze.

\section{BETEGEK ÉS MÓDSZEREK}

A Szegedi Tudományegyetem ÁOK Sebészeti Klinikáján 2005. január 1. és 2008. december 31. között 74 betegen végeztünk laparoscopos/laparoscoposan asszisztált colorectalis bélresectiót. A mütéti indikációt 40 esetben neoplasticus eredetü colorectalis laesio képezte (1. táblázat). A betegek átlagos életkora 64 év volt (36-89 év). A betegek közül 4 ASA I, 11 ASA II, 24 ASA III és 1 ASA IV rizikócsoportba tartozott.

A mütét előtti gasztroenterológiai kivizsgálás a hazai és a nemzetközi protokolloknak megfelelően történt. A kivizsgálás szerves részét képezte a colonoscopia, szövettani mintavétellel, hasi és kismedencei CT-, illetve MR-vizsgálat. A beteg aneszteziológiai kockázatának és mütéti teherbíró képességének megállapítására belgyógyászati, kardiológiai és szükség esetén tüdőgyógyászati szakvizsgálatra is sor került.

1. táblázat. Laparoscopos bélresectión átesett betegek adatai

\begin{tabular}{lc}
\hline Kor (év) & $64(36-89)$ \\
Férfi & 21 \\
Nő & 19 \\
BMI & $28(20-47)$ \\
ASA (\%) & \\
I & 4 \\
II & 11 \\
III & 24 \\
IV & 1 \\
\hline
\end{tabular}

\section{Mütéti kezelés}

Minden beteg a tervezett, nyitott mütéteknél alkalmazott standard preoperatív előkészítésben részesült: bélelőkészítés, antibiotikum és trombózisprofilaxis. Az intratrachealis narkózisban végzett mütéteket a nemzetközi standardoknak megfelelően kiviteleztük. A bal colonfél invazív tumorainál medio-lateralis irányú disszekció történt és az onkológiai radikalitás és staging miatt minden esetben elvégeztük az aortából történő eredésénél az arteria mesenterica inferior klippelését és átvágását is. A flexura lienalis mobilizálását csak szükség esetén végeztük el. Gépi anastomosisok készítésekor az ún. kettős stapler technikát alkalmaztuk (a distalis bélszakasz átvágása endoscopos varrógép segítségével történt). A tumoros bélszakasz hasüregből való eltávolítását a szeméremcsont felett ejtett, haránt (Pfannenstiel) metszésből, a hasizmok megkímélésével végeztük. A bél resectiója illetve a körkörös varrógép fejének bélbe helyezése a hasfal előtt történt. Infraperitonealis anastomosisokat a gát, míg az intraperitonealis varratsorokat a has felől drenáltuk. A dréneket a passage megindulását követően 24 órán belül eltávolítottuk.

Jobb oldali hemicolectomia végzésekor laparoscoposan mobilizáltuk a jobb colonfelet (flexura lienalist, colon transversumot) és a köldök magasságában jobb oldalon végzett $\mathrm{kb}$. $10 \mathrm{~cm}$-es rácsmetszésből előemeltük a hasfal elé a mobilizált bélszakaszt, majd a hasfal előtt történt maga a resectio és a bélcsatorna folytonosságának helyreállítása (end-to-side kézi anastomosis, seromuscularis egyrétegű tovafutó varrat) is.

Minden esetben hasfalvédelmet alkalmaztunk (3M hasfalvédő fólia). Kisebb tumorok vagy infraperitonealisan elhelyezkedő laesiók esetén intraoperatív endoscopiát alkamaztunk.

\section{EREDMÉNYEK}

A mütéten átesett betegek adatait az 1. táblázat foglalja össze. Kiemelendő, hogy a betegek $60 \%$-a magasabb (ASA III-IV) kockázati csoportba tartozott. Hasonlóképpen figyelemre méltó az is, hogy a magyar populációnak megfelelően, a betegek többsége jelentősen elhízott volt (az átlagos BMI 28).

Tekintettel a tumorok elhelyezkedésére, az esetek kétharmadában (65\%) recto-sigmoidealis resectio történt, közülük 4 esetben kényszerültünk konverzióra. 7 esetben alkalmaztunk intraoperatív endoscopos kontrollt. A műtéti beavatkozások során szövődményt nem észleltünk és csak minimális vérvesztés (átlagosan 100 $\mathrm{ml}$ ) volt. A posztoperatív szak - hasonlóképpen a mütéti kezeléshez - szövődménymentesen zajlott. Egy esetben kellett adhesiós ileus miatt relaparoscopiát végeznünk. A passage megindulása (átlagosan 2,4 nap) és a betegek szájon keresztüli táplálhatóságának ideje jelentősen lerövidült. A mütéti beavatkozások eredményeit a 2. táblázat foglalja össze. 


\section{2. táblázat. Mútéti beavatkozásokés eredményük}

\begin{tabular}{lc}
\hline \multicolumn{1}{c}{ Megnevezés } & Adatok \\
\hline Hemicolectomia sin. & 1 \\
Exstirpatio recti & 2 \\
Res. rectosigm. & 4 \\
Hemicolectomia dextra & 9 \\
Res. sigmatos & 12 \\
Res. recti & 12 \\
Mútéti idő (perc) & $195(100-340)$ \\
Vérvesztés (ml) & $100(50-400)$ \\
Passage megindulása (nap) & $2,4(1-5)$ \\
Ápolási idő (nap) & $7,15(4-27)$ \\
Morbiditás & \\
$\quad$ - sebfertőzés & \\
- varratelégtelenség & \\
- ileus & $\varnothing$ \\
Reoperáció & \\
Konverzió &
\end{tabular}

3. táblázat. Az eltávolitott bélresecatumok hisztopatológiai eredményei

\begin{tabular}{lc}
\hline \multicolumn{1}{c}{ Megnevezés } & Elöfordulás \\
\hline Malignus & 40 \\
Tu. coli transversi & 2 \\
Tu. coeci & 3 \\
Tu. col. ascendentis & 4 \\
Tu. sigmatos & 14 \\
Tu. recti & 17 \\
Neoadjuváns kezelés & 7 \\
T1 & 3 \\
T2 & 10 \\
T3 & 25 \\
T4 & 2 \\
N0 & 24 \\
N1 & 9 \\
N2 & 7 \\
Stádium & $10(8-23)$ \\
I & \\
II & 11 \\
III & 16 \\
IV & \\
Nyirokcsomók & \\
\hline
\end{tabular}

Az eltávolított bélszegmensek hisztológiai eredményeit a 3. táblázat foglalja össze. Kiemelendő, hogy az összes műtét során sebész-onkológiai szempontból is elégséges resectiók történtek, hisz mind az oralis, mind az aboralis és circumferentialis resectiós szegélyek szövettanilag tumormentesek voltak. A mütétek során megfelelő számú nyirokcsomó is eltávolításra ke- rült (átlagosan 10). Hasonlóképpen aláhúzandó, hogy a laparoscopos rectum-, rectosigmoidealis resectio 7 betegnél neoadjuváns kezelést követően történt.

\section{MEGBESZÉLÉS}

Már az első közlemények a laparoscopos colorectalis mútétek számos előnyérôl számoltak be, amit később randomizált klinikai tanulmányok is egyértelmúen megerősítettek. A laparoscopos vastagbélműtétek kapcsán az is igazolódott, hogy a mútéti trauma, a gazdaszervezet stresszválasza (elsősorban IL-1, IL-6, C reaktív protein) jóval alacsonyabb $(23,30,36)$, mint a nyitott mútéteknél. Nem elhanyagolható szempont, hogy jelentősen csökkent a műtét utáni fájdalom is $(16,32,34)$, és ennek következtében természetesen a fájdalomcsillapító-igény $(21,34)$. Hasonlóképpen a gyomor-bélrendszer (bélműködés megindulása, per os táplálhatóság) $(9,18$, $19,31)$ és a légzésfunkciók (FVC, FEV1) $(21,29)$ normalizálódása is rövidebb időn belül jött létre. Elsősorban ezek az előnyök csökkentették jelentősen a kórházi tartózkodást, és így meggyorsult a betegek rehabilitációja $(8,9,19,32,34)$ is. A legfrissebb és egyben a legnagyobb betegszámot bemutató retrospektív felmérés szerint, a fentebb részletezett előnyökön túl az is igazolható volt, hogy a laparoscopos vastagbél-resectióknak kevesebb a transzfúzióigénye és a szövődménye is, és rövidebb időt töltenek az intenzív osztályon (10). Saját klinikai tapasztalatunkban különösen a passage megindulásában és a szájon keresztüli táplálhatóság idejének lerövidülésében érezzük a legszembetűnőbb javulást. Az esetek többségében már a műtétet követő 2 . napon megindult a passage és a teljes szájon át táplálást is 4 nap alatt lehetett felépíteni. A kórházi kezelési idő is csökkent, azonban főleg az idős betegek, rossz otthoni körülményeik miatt, továbbra is hosszabban igénylik a kórházi törődést. Mútéteink során nem volt sem halálozás, sem jelentős morbiditás. Reoperációra egy esetben, adhesiók miatt került sor. Betegeinknél az egyik szembeötlő és örömteli tapasztalatunk az volt, hogy a sebgyógyulási problémák teljesen megszűntek.

\section{Lehetséges ellenjavallatok}

Általánosságban elmondható, hogy a preoperatív gasztroenterológiai kivizsgálás nem különbözik a hagyományos és laparoscopos mútétre érkező betegeknél. Természetesen a kivizsgálás szerves részét képezi a betegek általános és kardiopulmonális státusának pontos felmérése is. Önmagában a beteg életkora nem jelenthet kontraindikációt a laparoscopos technika alkalmazásánál $(9,28)$. Hasonlóképpen a fokozott kardiopulmonális rizikó sem zárja ki a minimálisan invazív technika alkalmazását. ASA III-IV rizikócsoportba tartozó betegek esetén a vérnyomás és a vérgáz szoros monitorizálása mellett alacsonyabb nyomású 
(<12 Hgmm) pneumoperitoneum fenntartása lehet indokolt (22). Klinikánkon sem a kor, sem a kardipulmonális státus nem képezett betegeinknél mütéti ellenjavallatot. Az idősebb és egyben magasabb rizikócsoportba tartozó betegeknél sem észleltünk magasabb arányban intra- vagy posztoperatív szövődményt. A harmadik komplikációs forrás, mely minden laparoscopos mütét kapcsán felmerül, az obesitas. Az elhízás nemcsak aneszteziológiai kockázatot rejt magában (csökkent respiratorikus reserve, magasabb belégzési rezisztencia stb.), hanem sebésztechnikai nehézségeket is okoz. A kisebb operációs tér nagymértékben korlátozza a mütét technikai kivitelezhetőségét is. Több megfigyelés szerint $(5,25,27) 30$ feletti BMI esetén növekszik a konverziós ráta és hasonlóképpen nő az egyéb szövődmények aránya is. Mindezek ellenére az obesitas sem jelent önmagában ellenjavallatot.

Beteganyagunkban speciális, magával a laparoscopos technikával összefüggésbe hozható mütéti kontraindikáció nem volt.

Jelenleg a legtöbb sebész egy valódi kontraindikációt fogalmaz meg, ez a daganat előrehaladott stádiuma (T4), és a daganatnak a környező szövetekre (hasfal, egyéb hasi szervek) való átterjedése, mivel a tumor előrehaladott lokális kiterjedése sok esetben nem teszi lehetővé a radikális, ún. en block resectio elvégzését. Ezzel a kijelentéssel sokan vitatkoznak (elsősorban a nagyobb tapasztalatú sebészek). Véleményük szerint ez valójában sebészi tapasztalat függvénye és nem technikai kérdés. Ilyen esetben többségük a kézzel asszisztált laparoscopos technika végzését javasolja. Ebbe a kérdéskörbe tartozik még a peritonealis carcinosis problematikája is. Általános vélemény, hogy a carcinosis sem jelent kontraindikációt, hiszen a laparoscopos módszer kiválóan alkalmas palliatív mütétek végzésére is. Betegeinknél két esetben távolítottunk el hasfallal összekapaszkodó tumort (T4). Mindkét esetben a szövettani feldolgozás ép, tumormentes resectiós széleket igazolt.

\section{Speciális sebészi-onkológiai megfontolások}

A colorectalis daganatok terápiájában az elváltozás radikális sebészi eltávolítása a legfontosabb kezelési eljárás, melynek jelenleg nincs alternatívája. Ezért lényeges, hogy egy új terápiás sebészi módszer bevezetésének következményeként az onkológiai alapelvek ne sérüljenek: így megfelelő hosszúságú bélszegmens (ép proximalis, distalis és circumferentialis resectiós szél) és elegendő számú locoregionalis nyirokcsomó kerüljön eltávolításra. Az eddig publikált randomizált $(8,9,19,21,32)$ és nem randomizált $(3,4)$ összehasonlító tanulmányok azt igazolják, hogy a bélszegmens nagysága, a tumor és a resectiós szélek viszonya és a nyirokcsomók száma tekintetében nincs különbség a nyitott és laparoscopos mütétek onkológiai radikalitása között. Saját eseteinkben a patológiai vizsgálatok mindig ép resectiós széleket és megfelelő számú nyirokcsomót igazoltak.

A laparoscopos mütét kapcsán a tapintás hiánya speciális technikák alkalmazását teszi szükségessé. Ezek közül a legfontosabb a tumorlokalizáció, mely kis tumorok esetén mindig ajánlott (kivéve az ileocoecalis billentyűhöz közeli elváltozásokat). Több módszert is alkalmazhatunk, mint (1) festékjelölés/ "tattooing", melyet már a diagnosztikus colonoscopia során elvégezhetünk (2), intraoperatív endoscopia (3), preoperatív klip jelölés (intraoperatív fluoroscopia/ UH) (4), kézzel asszisztált technika alkalmazása. Saját gyakorlatunkban az intraoperatív endoscopiát (sigmoideoscopia, colonoscopia) alkalmazzuk, melylyel eddig minden esetben azonosítani tudtuk az elváltozást vagy annak pontos helyét (malignus polypus esetén).

A 90-es évek első idevonatkozó irodalmában többen arról számoltak be, hogy nagy arányban tapasztaltak ún. port-site metastasisokat $(0,6-21 \%)(1,24,26)$, ez napjainkra már 1\%-ra csökkent $(6,35)$. Hogy mi az elfogadható arány, azt nehéz lenne megmondani, hiszen a kevés közlemény - mely nyitott mütétek kapcsán foglalkozik ezzel a kérdéssel - azt mutatja, hogy ez az érték ilyen esetekben is $0,7-3 \%$ között van $(10,11)$. Mütéteink kapcsán egy esetben észleltünk a palliatív mütétet követően fél évvel egy hasfali metastasist (a specimenkivétel helyén), melyet később eltávolítottunk.

Az elmúlt évtizedben számos szerző foglalkozott a port-site metastasisok csökkentésének módszertanával, melyek közül az alábbiak a legfontosabbak: (1) megfelelő mütéti technika/tapasztalat, (2) hasfal védelme, (3) gáz nélküli mütét, (4) egyéb gáz (hélium) alkalmazása, (5) sebkimetszés (6) „no touch” technika, (7) bél-átmosás. Ezek közül a legfontosabb a megfelelő sebészi technika és a hasfal védelme, melyek elsősorban T3-T4-es daganatoknál különös figyelmet érdemelnek.

\section{Operatív mortalitás/morbiditás, túlélés}

Napjainkig négy randomizált tanulmány látott napvilágot, mely tudományosan a legmagasabb szinten összehasonlította a laparoscopos és a hagyományos, nyitott colorectalis mütéteket $(7,11,12,18)$. A tanulmányok közül 3 multicentrikus volt, míg egy, a Barcelona vizsgálat, egy sebészeti intézet eredményeit foglalja össze. A vizsgálatok azt bizonyítják, hogy az operatív mortalitás és morbiditás tekintetében sincs különbség a csoportok között.

A négy tanulmány, beleértve a vizsgálatok metaanalízisét is (33), nem mutatott különbséget a nyitott és a laparoscopos csoport között sem a hosszú távú daganatos túlélés, sem a recidívák vonatkozásában. A barcelonai munkacsoport legutolsó beszámolója szerint - 95 hónapos átlagos nyomonkövetés után - a daganatmentes- és teljes túlélés jelentősen jobb volt a laparoscopos csoportban, melyben a túlélési előny csaknem elérte a 
szignifikanciaküszöböt (a különbség a legfeltűnőbb elsősorban III. stádiumú daganatok esetén volt) (20). A szerzők ezt a javuló tendenciát a laparoscopos mütét kisebb gyulladásos/immunológiai válaszreakciójával magyarázzák (20) („learning curve”, tanulási periódus).

A haladó laparoscopos mütétek biztonságos kivitelezéséhez megfelelő számú műtét elvégzése és megfelelő egyénre szabott gyakorlat elérése szükséges. Colorectalis mütétek kapcsán ez hozzávetőlegesen 20 mütét elvégzését jelenti (ebben adták meg a randomizált tanulmányhoz való csatlakozás minimális mütéti számát). Az, hogy ez a szám sok-e vagy kevés, alapvetően sebészspecifikus. Annyi azonban bizonyos, hogy a technikai jártasság egyik fokmérője a konverziós ráta, mely a megfelelő gyakorlat megszerzését követően fokozatosan csökken, majd stabilizálódik. Hasonlóképpen fokozatosan nő az eltávolított locoregionalis nyirokcsomók száma is, mely szintén a sebész technikai gyakorlatával hozható összefüggésbe.

Saját és a nemzetközi eredmények áttekintése alapján megállapíthatjuk, hogy a colorectalis daganatok miatt végzett laparoscopos mútétek biztonságosak, sebész-onkológiai szempontból is megfelelőek. Számos előnyt jelentenek a betegek számára elsősorban a korai posztoperatív időszakban (gyorsabb felépülés, rövidebb kórházi tartózkodás) és a hosszú távú onkológiai eredmények is kielégítőek. Más hazai $(2,17)$ és számos külföldi szerzővel egyetértésben megállapíthatjuk, hogy a laparoscopos technika a colorectalis rákok sebészi gyógyításában elfogadott kezelési módszerré vált.

\section{IRODALOM}

1. Berends FJ, Kazemier G, Bonjer HJ, et al. Subcutaneous metastases after laparoscopic colectomy. Lancet 344(8914):58, 1994

2. Bezsilla J, Bende S, Varga L és mtsai: Laparoszkópos vastagbélmütétek endoszkóposan nem eltávolítható polip és daganat miatt. Magyar Sebészet 58:305-311, 2006

3. Bokey EL, Moore JW, Chapuis PH, et al. Morbidity and mortality following laparoscopic-assisted right hemicolectomy for cancer. Dis Colon Rectum 39(10 Suppl):S24-S28, 1996

4. Bouvet M, Mansfield PF, Skibber JM, et al. Clinical, pathologic, and economic parameters of laparoscopic colon resection for cancer. Am J Surg 176:554-558, 1998

5. Buchanan GN, Malik A, Parvaiz A, et al. Laparoscopic resection for colorectal cancer. Br J Surg 95:893-902, 2008

6. Chapmen AE, Levitt MD, Hewett P, et al. Laparoscopic-assisted resection of colorectal malignancies: a systematic review. Ann Surg 234:590-606, 2001

7. The Colon Cancer Laparoscopic or Open Resection Study Group: laparoscopic surgery versus open surgery for colon cancer: shortterm outcomes of a randomized trial. Lancet Oncol 6:477-484, 2005

8. Curet MJ, Putrakul K, Pitcher DE, et al. Laparoscopically assisted colon resection for colon carcinoma: perioperative results and long-term outcome. Surg Endosc 14:1062-1066, 2000

9. Delgado S, Lacy AM, García Valdecasas JC, et al. Could age be an indication for laparoscopic colectomy in colorectal cancer? Surg Endosc 14:22-26, 2000

10. Delaney CP, Chang E, Senagore AJ, et al. Clinical outcomes and resource utilization associated with laparoscopic and open colectomy using a large national database. Ann Surg 247:819-824, 2008
11. Fleshman J, Sargent DJ, Green E, et al. Laparoscopic colectomy for cancer is not inferior to open surgery based on 5-year data from the COST Study Group trial. Ann Surg 246:655-662, 2007

12. Guillou PJ, Quirke P, Thorpe H, et al. Short-term endpoints of conventional versus laparoscopic assisted surgery in patients with colorectal cancer (MRC CLASSIC trial): multicentre, randomized controlled trial. Lancet 365:1718-1726, 2005

13. Gunderson LL, Sosin H. Areas of failure found at reoperation (second or symptomatic look) following "curative surgery" for adenocarcinoma of the rectum. Clinicopathologic correlation and implications for adjuvant therapy. Cancer 34:1278-1292, 1974

14. Hughes ESR, McDermott FT, Polglase AL, et al. Tumor recurrence in the abdominal wall scar after large-bowel cancer surgery. Dis Colon Rectum 26:571-572, 1983

15. Jacobs M, Verdeja JC, Goldstein HS. Minimally invasive colon resection (laparoscopic colectomy). Surg Laparosc Endosc 1:144-150, 1991

16. Kohler L, Holthausen U, Troidl H. Laparoscopic colorectal surgery - attempt at evaluating a new technology. Chirurg 68:794-800, 1997

17. Kupcsulik P. Laparoszkópos colorectalis sebészet. Magyar Sebészet 59:79-90, 2006

18. Lacy AM, García-Valdecasas JC, Delgado S, et al. Laparoscopyassisted colectomy versus open colectomy for treatment of nonmetastatic colon cancer: a randomised trial. Lancet 359:2224-2229, 2002

19. Lacy AM, García-Valdecasas JC, Piqué JM, et al. Short-term outcome analysis of a randomized study comparing laparoscopic vs open coloctomy for colon cancer. Surg Endosc 9:1101-1105, 1995

20. Lacy AM, Delgado S, Castells A, et al. The long-term results of a randomized clinical trial of laparoscopy-assisted versus open surgery for colon cancer. Ann Surg 248:1-7, 2008

21. Milsom JW, Böhm B, Hammerhofer KA, et al. A prospective, randomized trial comparing laparoscopic versus conventional techniques in colorectal cancer surgery: a preliminary report. J Am Coll Surg 187:46-54, 1998

22. Neudecker J, Sauerland S, Neugebauer E, et al. The European Association for Endoscopic Surgery clinical practice guideline on the pneumoperitoneum for laparoscopic surgery. Surg Endosc $16: 1121-1143,2002$

23. Nishiguchi K, Okuda J, Toyoda M, et al. Comparative evaluation of surgical stress of laparoscopic and open surgeries for colorectal carcinoma. Dis Colon Rectum 44:223-230, 2001

24. Ortega AE, Baril N, Lara SR, et al. Does peritoneal mobilization increase laparoscopic acidosis? Dis Colon Rectum 38:1296-1300, 1995

25. Pandya S, Murray JJ, Coller JA, et al. Laparoscopic colectomy: indications for conversion to laparotomy. Arch Surg 134:471-475, 1999

26. Pfeifer J, Reissman P, Wexner SD. Ergotamine-induced complex rectovaginal fistula. Report of a case. Dis Colon Rectum 38:12241226, 1995

27. Pikarsky AJ, Saida Y, Yamaguchi T, et al. Is obesity a high risk factor for laparoscopic colorectal surgery? Surg Endosc 16:855-858, 2002

28. Schwandner O, Schiedeck TH, Bruch HP. Advanced age - indication or contraindication for laparoscopic colorectal surgery? Dis Colon Rectum 42:356-362, 1999

29. Schwenk W, Böhm B, Witt C, et al. Pulmonary function following laparoscopic or conventional colorectal resection: a randomized controlled evaluation. Arch Surg 134:6-12, 1999

30. Schwenk W, Jacobi C, Mansmann U, et al. Inflammatory response after laparoscopic and conventional colorectal resections-results of a prospective randomized trial. Langenbecks Arch Surg 385:2-9, 2000

31. Schwenk W, Böhm B, Haase O, et al. Laparoscopic versus conventional colorectal resection: a prospective randomised study of postoperative ileus and early postoperative feeding. Langenbecks Arch Surg 383:49-55, 1998 